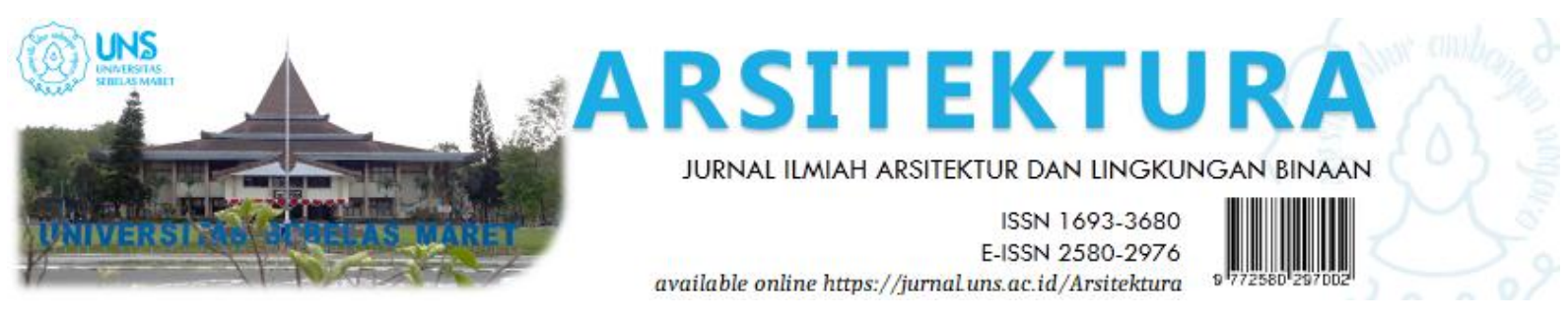

Volume 17 Issue 2 October 2019, pages:169-176

\title{
Strategi Desain Konsep Permakultur pada SMK Pertanian di Kabupaten Grobogan
}

\section{Design Strategy of Permaculture Concept on Agricultural Vocational School in Grobogan}

\author{
Rizkia Rahmani Maulana ${ }^{1 *}$, Suparno ${ }^{2}$, Ana Hardiana ${ }^{3}$ \\ Program Studi Arsitektur, Fakultas Teknik, Universitas Sebelas Maret* \\ Email : rizkiarahmani@gmail.com* \\ Program Studi Arsitektur, Fakultas Teknik, Universitas Sebelas Maret ${ }^{2}$ \\ Program Studi Arsitektur, Fakultas Teknik, Universitas Sebelas Maret ${ }^{3}$
}

DOI: https://doi.org/10.20961/arst.v17i2.24152

Received: September 21, 2018 Revised: October 14, 2018 Accepted: October 17, 2019 Available online:October 31, 2019

\begin{abstract}
Grobogan Regency is one of the regions that has high agricultural potential. However, the existing educational facilities cannot accommodate all existing communities. Education in agriculture is found as lacking where not all regions who potentially in agriculture have agriculture-based educational institutions. Agricultural Vocational High School with the concept of permaculture in Grobogan provides five departments in agriculture with a three-year study period. Planning method in this design using planning, programming and designing which related to permaculture concept. Permaculture is the basis for ecological and independent building design by emphasizing the main principles of permaculture; energy planning, energy cycle, scale, biological sources and related locations that are in accordance with the needs of the education and agriculture regions. Design of agricultural vocational school emphasizes on zoning in building and sector. The result of the school design is to create an independent school area with maximum energy planning and to display related agricultural school buildings.
\end{abstract}

Keywords: agricultural vocational high school, permaculture, Grobogan

\section{PENDAHULUAN}

Indonesia memiliki wilayah yang potensial dalam bidang pertanian. Dalam Renstra Kementrian Pertanian tahun 2015-2019 menyebutkan bahwa RPJMN tahap-3 (20152019), sektor pertanian masih memiliki peranan penting dalam pembangunan nasional.

Pendidikan juga menjadi sarana pendukung dalam pertumbuhan ekonomi dengan tersedianya tenaga kerja yang terampil dan produktif dalam bidang pertanian. Namun, fenomena yang ada menunjukkan kendala serius dalam pembangunan sektor pertanian yaitu rendahnya kualitas pendidikan dan SDM pertanian. Selain itu hilangnya minat generasi muda terhadap pertanian ini menyebabkan kesenjangan regenerasi di sektor pertanian yang berimbas pada menurunnya jumlah bahan pangan yang dihasilkan (Kemetrian Pertanian, 2015).

Grobogan merupakan salah satu kabupaten di Jawa Tengah dengan potensi pertanian yang cukup baik. Sebanyak 83\% lahannya adalah lahan produktif pertanian dengan surplus padi 
yang terus meningkat sebesar 622.715 ton pada 2013, 555.784 ton pada $2014,766.040$ ton pada 2015 dan 827.508 ton pada tahun 2017 (Badan Pusat Statistik, 2017).

Namun, pertanian di Grobogan juga memiliki tantangan baik dibidang pertanian itu sendiri maupun dibidang pendidikan. Dalam bidang pertanian, Kabupaten Grobogan memiliki tantangan akan alih fungsi lahan lahan pertanian yang menyebabkan penurunan kualitas lahan. Terlebih lagi, tingkat regenerasi petani dan pengetahuan pertanian yang minim menjadi ancaman dalam kualitas produksi pertanian (Badan Pusat Statistik, 2017).

SMK Pertanian sendiri merupakan pendidikan formal berbasis kejuruan dalam bidang ilmu pertanian untuk mencetak tenaga ahli dan terampil yang siap bekerja dalam bidang terkait(Yuniar Irkham Fadlli, Soedwiwahjono, 2016).

Data pokok SMK tahun 2017 menyebutkan Kabupaten Grobogan sendiri hanya baru memiliki 1 buah SMK dengan prodi pertanian yaitu SMK N 1 Wirosari. Dalam Renstra SMK 2015-2019 oleh Kementrian Pendidikan dan Kebudayaan (2015) menyebutkan adanya target pembangunan minimal 600 SMK pertanian unggulan hingga tahun 2019.

Isu pemanasan global, perubahan iklim, penggunaan energi berlebih hingga kerusakan alam menjadi tantangan dalam penyelesaian desain bangunan. Rancangan SMK Pertanian mengaplikasikan konsep permakultur dalam desain.

Permakultur yang ada dalam buku A Resource Book for Permaculture : Solution for Sustainable Lifestyles oleh Lachlan McKenzie diartikan sebagai pengelolaan pertanian dan peternakan dalam peningkatan kualitas lahan yang berkelanjutan dan mendukung kerjasama dengan budaya dan lingkungan setempat (Permatil, 2006). Permakultur dalam aplikasinya mengintegrasikan lahan dengan bangunan untuk meminimalkan dampak negatif pada bangunan. Selain itu, siklus energi yang digunakan juga lebih produktif dan efisien sehingga menunjang perancangan yang selaras dengan alam (Mollison, 2009).

Konsep permakultur berfungsi sebagai strategi desain dalam merancang bangunan SMK
Pertanian di Kabupaten Grobogan dalam memaksimalkan efisiensi energi bangunan, integrasi bangunan dan lahan pertanian yang selaras dengan alam dan lingkungan sekitar(Amalia Dian Utami, Sri Yuliani, 2017). Oleh karena itu perancangan SMK Pertanian dengan pendekatan konsep permakultur di Kabupaten Grobogan menjadi relevan mengingat kebutuhan disektor pertanian dan segi pendidikan.

\section{METODE}

Perancangan Sekolah Menengah Pertanian (SMK) menggunakan metode perancangan planning, programming and designing yang mentransformasikan pendekatan Permakultur pada desain yang dirancang sebagai penyelesaian masalah dalam proses desain (Permatil, 2006).

Pemahaman Permakultur diawali dengan isu mengenai pertanian dan fenomena pendidikan dibidang pertanian yang kemudian dikaitkan dengan tinjauan data. Teori permakultur menjadi dasar utama sebagai data primer yang kemudian digunakan dalam tinjauan pustaka baik berasal dari jurnal, buku, maupun artikel terkait. Pembahasan lebih lanjut terfokus pada penerapan strategi desain permakultur pada SMK Pertanian.

Penerapan strategi desain permakultur diaplikasikan pada lima aspek perancangan yaitu pengolahan tapak, pengolahan bentuk dan tata massa, pengolahan tampilan, pengolahan struktur dan pengolahan utilitas.

\section{a. Pengolahan Tapak}

Strategi desain permakultur pada perencanaan yang digunakan adalah mengacu prinsip lokasi berhubungan dan sumber-sumber biologi dimana tapak terpilih memiliki akses, potensi dan sesuai dengan peraturan yang ada.

\section{b. Pengolahan Bentuk dan Tata Massa}

Bentuk dan tata massa bangunan SMK Pertanian menggunakan strategi desain zoning permakultur dimana tata massa dikelompokkan sesuai dengan intensitas dan penggunaan bangunan. Permakultur sendiri mengacu pada respon iklim dengan bentuk bangunan yang pipih dan memanjang. 


\section{c. Pengolahan Tampilan Bangunan}

Strategi desain permakultur yang digunakan fokus pada pemilihan material lokal dan menekankan pada kebudayaan lokal setempat. Hal ini ditunjang dengan prinsip permakultur sumber-sumber biologi dan skala sehingga dapat menunjang aspek estetika dan tampilan SMK Pertanian.

\section{d. Pengolahan Struktur}

Pengolahan struktur mengacu pada sistem struktur untuk menunjang kekuatan dan daya tahan bangunan terhadap lingkungan/ respon iklim, disamping selaras dengan alam. Strategi desain permakultur difokuskan dalam pemilihan sistem struktur dan material struktur yang sesuai dengan lokasi perancangan.

\section{e. Pengolahan Utilitas}

Pengolahan utilitas dalam strategi desain mengacu pada prinsip permakultur perencanaan energi dan siklus energi. Pengolahan utilitas difokuskan dalam pengolahan energi yang ada pada tapak sehingga energi yang ada dapat digunakan oleh bangunan secara mandiri dan independen serta meminimalkan energi yang terbuang/ sisa.

\section{HASIL DAN PEMBAHASAN}

Desain SMK Pertanian mengaplikasikan teori Permakultur dimana strategi desain mengacu pada prinsip permakultur yaitu perencanaan energi, siklus energi, sumber-sumber biologi, skala, dan lokasi berhubungan(Yusak Hartanto Gondo, Hardiyati, 2017).

Prinsip permakultur yang digunakan antara lain (1)Perencanaan energi. Perencanaan energi dilakukan dengan memanfaatkan energi dan sumber-sumber yang ada dilakukan secara maksimal untuk menghemat energi dan biaya. pemanfaatan biogas, solar cell merupakan salah satu cara pemanfaatan energi alami. (2) Siklus energi. Permakultur memiliki prinsip bahwa dalam sistem alami tidak ada limbah/polusi dimana sisa dari suatu proses akan menjadi sumber untuk proses lainnya. Hal ini sama dengan prinsip rantai makanan dimana tidak ada sisa yang tidak dapat digunakan. Oleh karena itu adanya pemanfaatan kembali sumber alam sebagai siklus energi dalam bangunan. (3)Skala. Prinsip skala diwujudkan pada desain dengan kesederhanaan dan sesuai ditampilkan melalui bentuk yang efisien serta rancangan bangunan yang mengikuti aliran energi secara dinamis. (4) Sumber-Sumber biologi. Sumber-sumber biologi digunakan pada penggunaan bahan dalam desain bangunan baik secara interior, eksterior maupun material bangunan. (5). Lokasi berhubungan. prinsip lokasi berhubungan digunakan sebagai pertimbangan lokasi yang paling ideal.

Penerapan permakultur pada perancangan SMK menghasilkan sekolah pertanian yang terintegrasi dengan lingkungan dan alam serta sumber energi bangunan yang mandiri.

Desain SMK pertanian dihasilkan melalui lima aspek perancangan yaitu pengolahan tapak, pengolahan, pengolahan bentuk dan tata massa, pengolahan tampilan, pengolahan struktur dan pengolahan utilitas dengan mengacu pada strategi desain dan prinsip permakultur.

\section{A. Pengolahan Tapak}

\section{Pemilihan Tapak}

Kriteria pemilihan tapak pada perancangan SMK ini antara lain (1) Kesesuaian dengan RTRW Kabupaten sebagai area pendidikan, (2) memiliki potensi pertanian yang tinggi, (3) memiliki kemudahan akses. Berdasarkan kriteria tersebut dapat diperoleh lokasi tapak yang sesuai. Tapak berada di Kecamatan Toroh dengan luasan $25.000 \mathrm{~m}^{2}$ yang dapat diakses dari jalan Gendingan-Boloh.

\section{Pencapaian Tapak}

Tapak berada dipersimpangan GendinganBoloh dan jalan Kartini. Untuk kemudahan akses diletakkan Main entrance pada Jalan Gendingan Boloh. Untuk akses pengelola dan siswa diletakkan pada side entrance yaitu di Jalan Kartini dengan satu jalur akses.

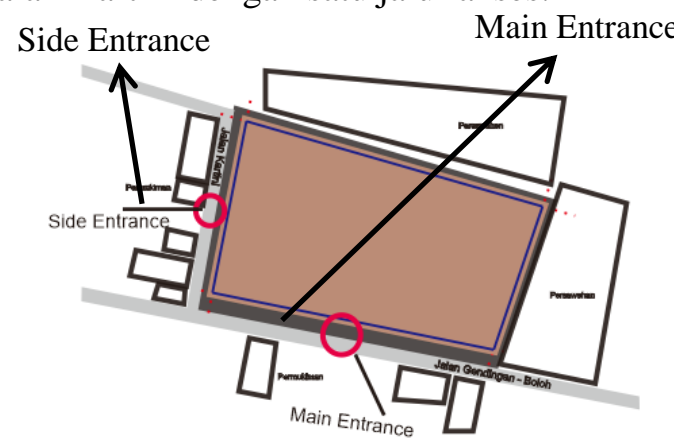

Gambar 1. Pencapaian tapak 


\section{Klimatologi pada Tapak}

Klimatologi pada tapak memiliki intensitas penyinaran matahari yang cukup tinggi dan sepanjang hari karena dikelilini persawahan. Untuk mengatasi panas pada bangunan, dilakukan peletakan massa sesuai dengan ruang dan kegiatannya dengan bentuk memanjang dan tipis serta pemberian vegetasi.

Potensi angin pada tapak juga cukup tinggi yang berhembus dari selatan ke utara. Peletakan bukaan serta konfigurasi massa bangunan mempengaruhi penghawaan pada bangunan. Selain itu digunakan juga penahan angin dengan deretan pohon.

Tapak juga memiliki hujan yang cukup tinggi di musim hujan dan kering dimusim kemarau. Pada sisi utara tapak terdapat saluran DAS (Daerah Aliran Sungai) Kecamatan TorohBoloh yang dapat digunakan sebagai sarana limpahan air hujan dan pengairan tapak.

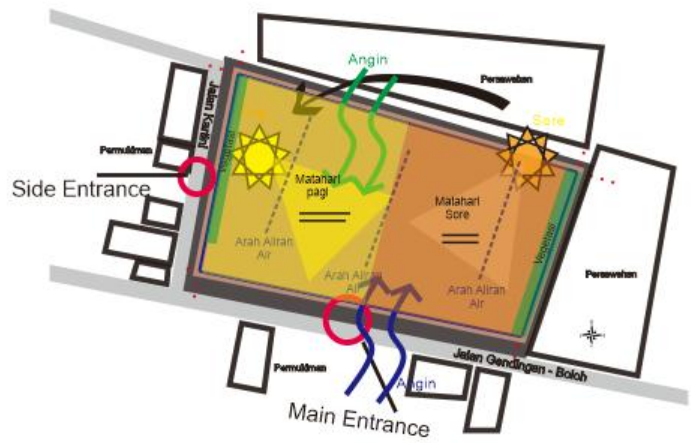

Gambar 2. Konsep Klimatologi pada tapak

\section{Zoning pada Tapak}

Zoning pada tapak mengacu pada konsep permakultur yaitu zonasi permakultur yang terbagi atas 5 zona massa (Holmgren, 2002).

- Zona 1 ; Zona yang paling vital dalam intensitas penggunaan, pemeliharaan maupun utilitasnya. Biasanya merupakan bangunan/rumah

- Zona 2 ; Zona yang lebih terbuka. Biasanya merupakan area infrastruktur, sarana dan prasarana yang mendukung dalam kegiatan pertanian dalam suatu kasawan.

- Zona 3 ; merupakan zona transisi yang berhubungan dengan zona $1 \& 2$

- Zona 4 : Merupakan zona pertanian. Biasanya berupa lahan pertanian atau perkebunan dan hewan.
- Zona 5 : Merupakan zona terluar yang berfungsi sebagai batasan tapak dengan daerah lainnya. Biasanya dilingkupi oleh tanaman pelindung ataupun pagar.

Tata massa bangunan ditentukan dengan analisis peruangan. Hasil dari analisis peruangan menghasilkan kebutuhan ruang dalam SMK Pertanian. Ruang dalam SMK Pertanian ini akan dibagi dalam beberapa kelompok sesuai dengan kebutuhan, fungsi dan intensitas penggunaannya untuk memudahkan jenis kegiatan yang dilakukan. Kelompok ruang terbagi atas Area Pembelajaran Teori, Area Praktik, Area Pengelola dan Guru, Area Penunjang dan Area Servis.

Zoning bangunan pada tapak terbagi atas kelompok ruang sesuai dengan zoning permakultr sebagai berikut;

- Zona $1 \rightarrow$ Area teori ; area kegiatan utama yang membutuhkan ketenangan. Intensitas penggunaan dan fungsi penggunaan siswa tinggi.

- Zona $2 \rightarrow$ Area praktik ; area ruang laboratorium membutuhkan ketenangan sedang dan dekat dengan area teori dan lahan pertanian

- Zona $3 \rightarrow$ Area pengelola dan guru ; area yang memiliki area penerimaan. Untuk ruang guru diletakkan dibelakang ruang pengelola

- Zona $4 \rightarrow$ Area penunjang ; area yang memiliki intensitas penggunaan rendah dan kebisingan yang sedang. Merupakan area transisi

- Zona $5 \rightarrow$ Area servis ; area yang memiliki intensitas paling rendah. Area ini dapat diletakkan didekat area praktik

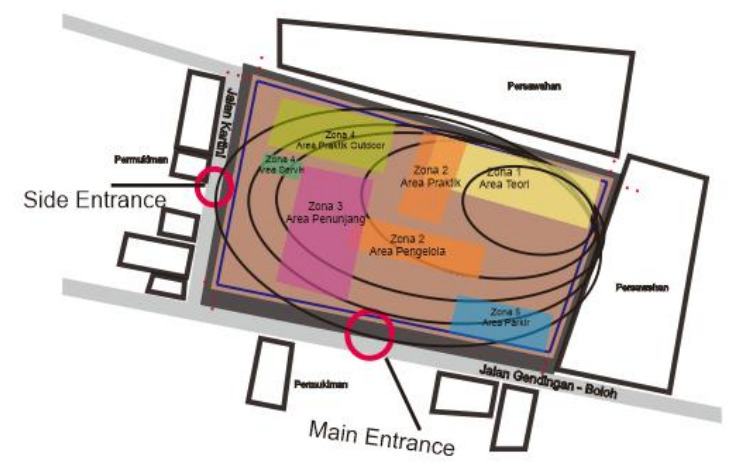

Gambar 3. Zoning Tapak 


\section{B. Pengolahan Bentuk dan Tata Massa}

Pengolahan bentuk dan tata massa dianalisis untuk menentukan bentuk dasar massa bangunan yang dapat merespon iklim dari sisi permakultur. Iklim yang ada merupakan iklim tropis dimana penyinaran matahari, air hujan dan angin menjadi faktor utama dalam strategi desain. Bentuk bangunan yang pipih dan memanjang dengan orientasi bangunan ke arah selatan dan utara serta pemberian sunshading dan pembayangan menjadi strategi desain dalam pengolahan bentuk bangunan.

Keputusan desain bentuk massa yang diambil adalah bentuk dasar persegi karrena kebutuhan efisiensi ruang. Selanjutnya bentuk massa disesuaikan dengan penambahan dan pengurangan sesuai kebutuhan.

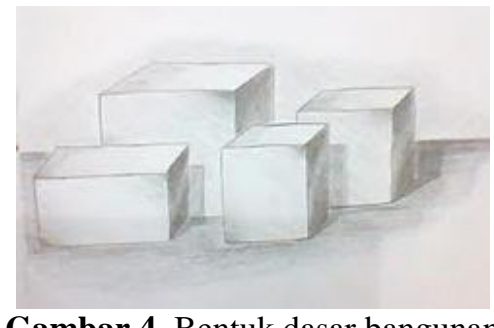

Gambar 4. Bentuk dasar bangunan

Perancangan tata massa bangunan sesuai dengan kaidah zoning pada permakultur dimana massa bangunan terbagi atas beberapa massa dengan kelompok ruang yang kemudian ditata sesuai dengan zoning yang ada.

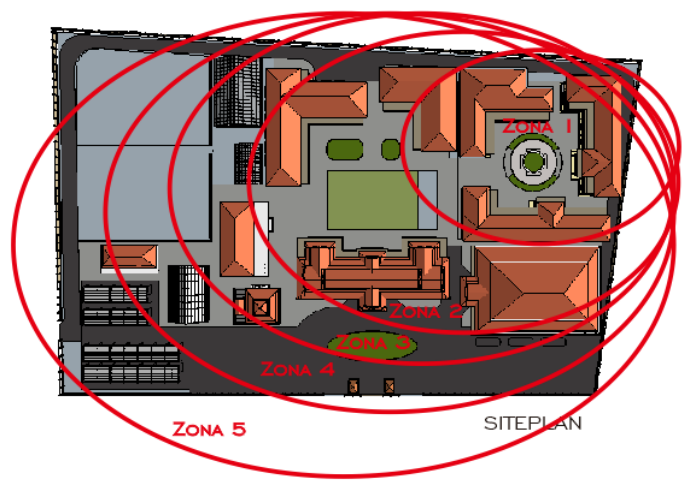

Gambar 5 . Tata Massa Bangunan

\section{Pengolahan Tampilan Bangunan}

Pengolahan tampilan pada SMK mengacu pada prinsip permakultur sumber-sumber biologi dan skala. Sumber-sumber biologi diterapkan pada tampilan bangunan SMK Pertanian merujuk pada konsep permakultur yaitu penggunaan material alam lokal untuk menampilkan kebudayaan lokal setempat. Sedangkan prinsip skala, bangunan yang dirancang merujuk pada skala manusia yang sesuai.

Material batu alam diaplikasikan pada dinding, jalan setapak dengan pengolahan yang sesuai dengan desain bangunan Untuk material bambu digunakan sebagai dinding partisi, sekondary skin, maupun struktur selasar sebagai pendukung bangunan.

Pada atap bangunan menggunakan atap joglo pada area penerimaan dan atap limasan pada bangunan dengan menggunakan lisplank bergerigi untuk menegaskan cirikhas bangunan.

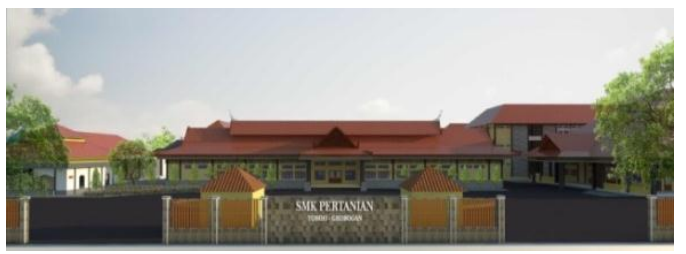

Gambar 6. Tampak depan SMK Pertanian

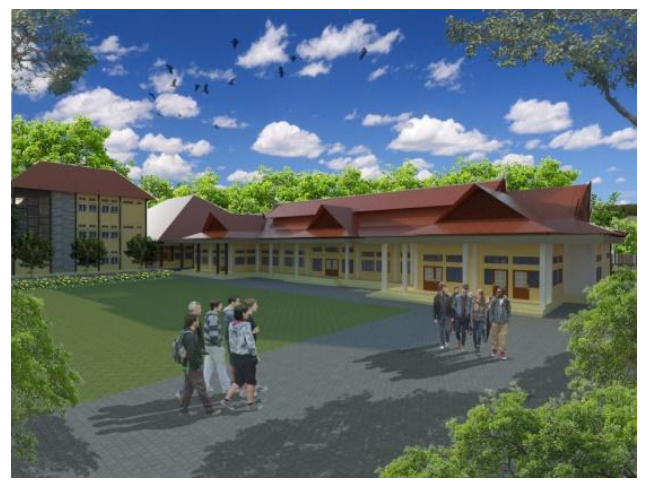

Gambar 7. Perspektif SMK Pertanian

\section{Pengolahan Struktur}

Struktur bangunan pada SMK juga merujuk pada konsep permakultur yaitu penggunaan struktur yang memiliki tingkat durabilitas yang tinggi dengan penggunaan material alam lokal.

- Kabupaten Grobogan memiliki jenis tanah lempung dengan plastisitas yang tinggi. Oleh karena itu bangunan SMK Pertanian yang dirancang, menggunakan pondasi footplat untuk seluruh area bangunan karena kondisi tanah Kab. Grobogan yang tidak stabil. Untuk area rawan menggunakan pondasi sumuran pada bangunan 2-3 lantai. 

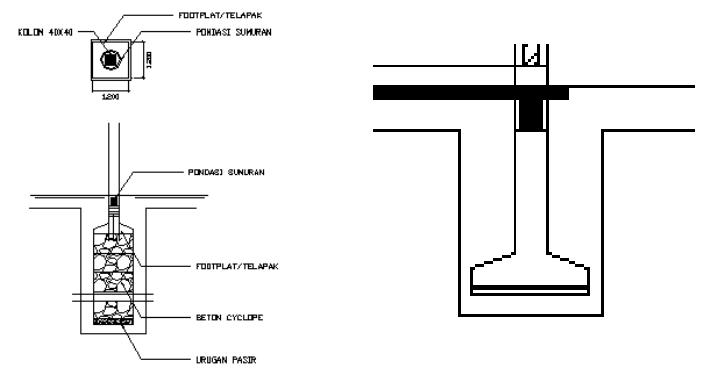

Gambar 8. pondasi sumuran dan footplat

- Untuk Super Struktur bangunan menggunakan tipe Rigid Frame yaitu sistem rangka kolom dan balok yang dihubungkan secara kaku untuk membentuk bidang vertikal dan horizontal. Sistem ini sesuai dengan kebutuhan ketahanan bangunandan teori permakultur.

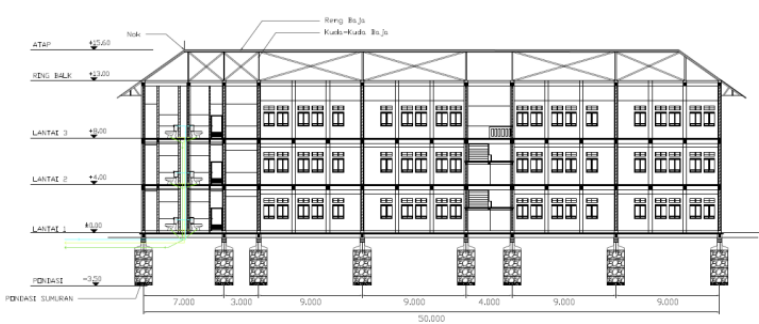

Gambar 9. Sistem rigid frame bangunan

- Bagian Upper struktur menggunakan atap bentuk limasan dan joglo yang menunjukkan merupakan ciri khas daerah dan respon iklim tropis. Untuk mempertegas fasad bangunan diberikan lisplank bergerigi. Material yang digunakan adalah struktur baja untuk ketahanan dan durabilitas bangunan yang baik. Area bertingkat menggunakan struktur plat beton yang atapnya dikombinasikan dengan atap dak dan dilapisi roof garden (Green Roof).

\section{E. Pengolahan Utilitas}

Sistem Utilias pada bangunan terbagi atas pengolahan air kotor, pengolahan air bekas dan air hujan, pengolahan sumber energi pada bangunan. Hal ini bertujuan untuk memanfaatkan energi yang ada dialam dan mengolah zat buangan secara maksimal.

\section{Pengolahan Air Bersih}

Pemenuhan air bersih pada bangunan didapatkan dari sumber air berupa PDAM dan sumur tanah. Selain itu menggunakan pengolahan air sisa dari air hujan dan air limbah untuk menyiram tanaman.

Air dari PDAM dan Sumur didistribusikan dengan menggunakan Down Feed System yaitu, dengan menampung air di tangki atas kemudian didistribusikan melalui pipa ke seluruh bangunan.

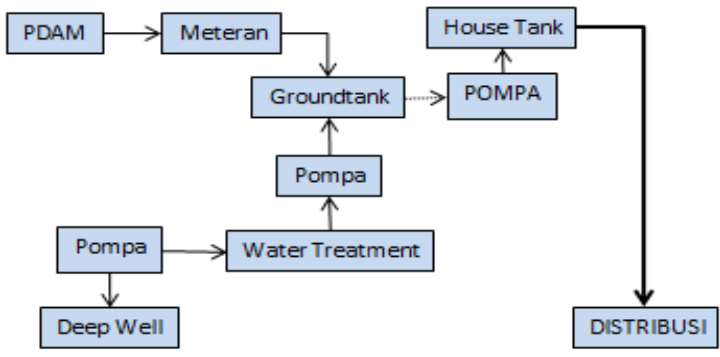

Gambar 10. Pengolahan Energi Listrik

\section{Pengolahan Air Kotor (Black Water)}

Air kotor hasil Lavatory dan limbah manusia baik padat maupun cair dipisahkan dalam limbah tidak berbahaya dan limbah berbahaya. Untuk limbah tidak berbahaya diolah dalam Biodigester yang kemudian menghasilkan biogas dan limbah padat.

Hasil biogas digunakan untuk menyokong kebutuhan listrik di sekolah. Sedangkan limbah padat hasil iodigester ditampung dan digunakan sebagai pupuk pada lahan pertanian.

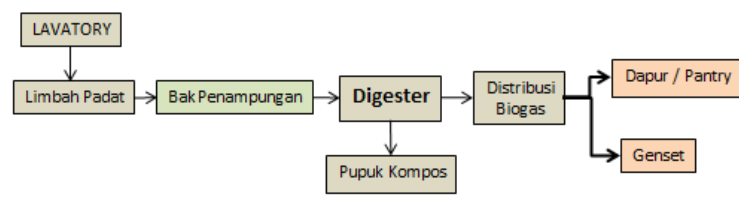

Gambar 11. Pengolahan Air Kotor

\section{Pengolahan Air Bekas dan Air Hujan}

Pemenuhan air bersih dilakukan pengolahan air sisa dan air hujan. Pengolahan air sisa dilakukan dengan cara alami yaitu menggunakan bak filter yang kemudian didistribusikan untuk menyiram tanaman 


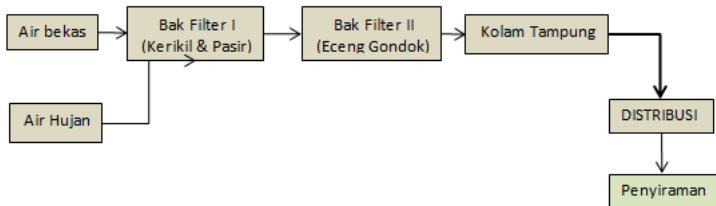

Gambar 12. Pengolahan Air Bekas dan Air Hujan

\section{Pengolahan Sampah}

Sampah hasil sisa dalam kegiatan yang ada di SMK Pertanian diolah untuk mengurangi sisa sampah tak terurai. Sampah dalam bangunan ini terbagi atas 3 macam yaitu sampah organik, sampah anorganik, sampah berbahaya dari laboratorium. Sampah organik diolah dengan menggunakan komposter untuk mendapatkan pupuk kompos sebagai pengganti pupuk anorganik.

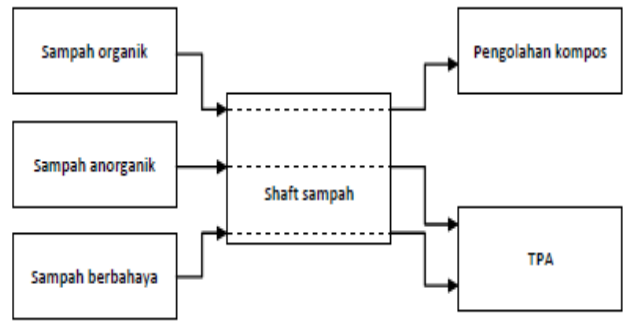

Gambar 13. Pengolahan Energi Listrik

\section{Pengolahan Energi listrik}

Pemenuhan kebutuhan listrik, bangunan menggunakan jaringan listrik dari PLN. Selain itu untuk kemandirian bangunan, listrik juga dihasilkan dari panel surya sebagai suplay listrik

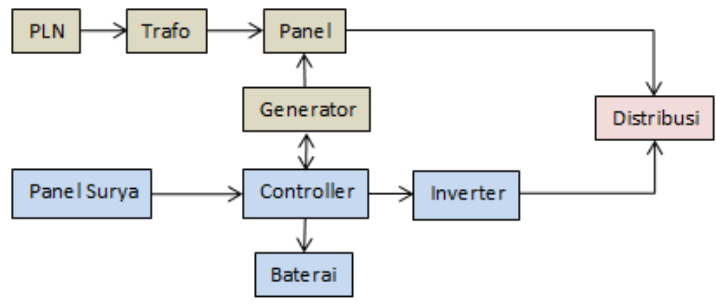

Gambar 14. Pengolahan Energi Listrik

\section{Penanggulangan Kebakaran}

Sistem kebakaran pada bangunan digunakan Fire Alarm dan Springkler yang dipasang disetiap ruangan, terutama ruangan vital seperti ruang kelas, ruang laboratorium, ruang pengelola dan guru. Selain itu disediakan tabung Hydrant di setiap sisi bangunan.

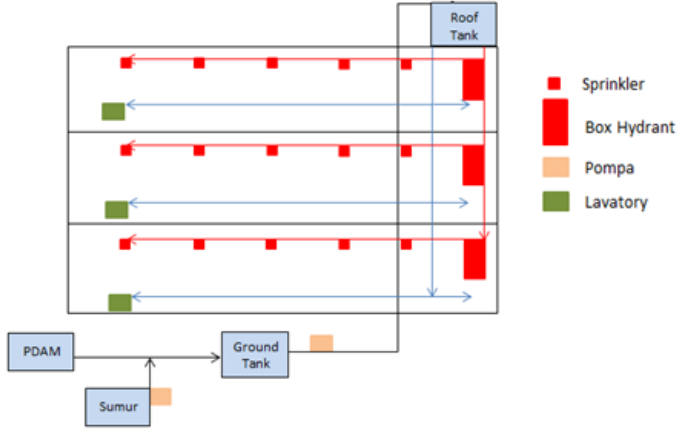

Gambar 15. Pengolahan Energi Listrik

\section{KESIMPULAN}

SMK Pertanian dengan Pendekatan Permakultur ini dirancang dengan mengintegrasikan bangunan pendidikan dan area pertanian yang ramah lingkungan dan dapat menjadi sarana pendidikan dan pembelajaran berbasis pertanian. Perancangan SMK ini dilakukan dengan prinsip permakultur melalui perencanaan energi, siklus energi, skala, sumber-sumber biologi serta lokasi yang berhubungan. Prinsip ini menjadi dasar dalam analisis perencanaan dan peancangan.

Zoning pada tapak mengacu pada prinsip zonasi permakultur yang terbagi atas lima zona. Hasil zonasi kemudian diaplikasikan pada penempatan kelompok area yang sesuai. Kelompok ruang dalam SMK yaitu ruang area teori, ruang area praktek, ruang area pengelola dan guru, ruang area penunjang dan ruang area servis. Pengelompokkan ruang ini kemudian dapat di zonasikan sesuai zoning dalam permakultur.

Massa tersebut diolah dengan tata massa yang sesuai dengan landscape dan zoning tapak yaitu massa bangunan pipih dan memanjang. Tampilan pada bangunan juga menyesuaikan budaya lokal setempat yaitu penggunaan atap miring dan penggunaan lisplank bergerigi dan penggunaan material alam lokal lingkungan sekitar. Penggunaan pondasi sumuran merupakan salahsatu cara dalam perbaikan tanah yang cukup labil didaerah tersebut.

SMK Pertanian ini juga dirancang dengan sistem utilitas dengan mengolah sumberdaya alam dan energi yang ada secara maksimal dan efisien sehingga bangunan dapat mandiri. 
Utilitas yang ditekankan pada SMK ini antara lain, pengolahan air bersih, pengolahan air kotor, pengolahan air sisa, pengolahan sampah, pengelolaan jaringan komunikasi dan listrik, penanggulangan kebakaran, sistem penangkal petir dan perawatan bangunan.

\section{REFERENSI}

Amalia Dian Utami, Sri Yuliani, U. M. (2017). Penerapan Arsitektur Ekologis Pada Strategi Perancangan Sekolah Menengah Kejuruan Pertanian Di Sleman. Jurnal Arsitektura, https://doi.org/http://dx.doi.org/10.20961/ arst.v15i2.15402.

Holmgren, D. (2002). Permaculture Principles \& Pathways Beyond Sustainability. Holmgren Design Services.

Mollison, B. (2009). Permaculture - A Designers Manual (Second Edi). Tasmania, Australia: A Tagari Publication.

Permatil. (2006). A Resource Book for Permaculture: Solution for Sustainable Lifestyles (First). Bali: Yayasan IDEP. Retrieved from www.idepfoundation.org.

Yuniar Irkham Fadlli, Soedwiwahjono, A. H. (2016). Faktor Yang Mempengaruhi Konversi Lahan Pertanian Studi Kasus : Kecamatan Jaten , Kabupaten Karanganyar. Jurnal Arsitektura, 14. https://doi.org/http://dx.doi.org/10.20961/ arst.v14i1.9220.

Yusak Hartanto Gondo, Hardiyati, K. N. H. (2017). Strategi Perancangan Sekolah Alam Smk Pertanian Dengan Pendekatan Sistem Permakultur Di Purbalingga. Jurnal Arsitektura, 15. https://doi.org/http://dx.doi.org/10.20961/ arst.v15i1.12196.

$$
\text { (2015). Rencana Strategis }
$$
Kementrian Pertanian Tahun 2015-2019. Jakarta. Retrieved from http://www.pertanian.go.id/file/RENSTR A_2015-2019.pdf. - (2017). Kabupaten Grobogan Dalam Angka. BPS Kabupaten Grobogan. Retrieved from www.grobogankab.bps.go.id 